\title{
EFFECTS OF E-LEARNING IN BASIC TRANSLATION COURSE FOR THE ENGLISH PRE-SERVICE TEACHERS
}

\author{
Kanokkarn Kittichartchaowalit*
}

Suratthani Rajabhat University

\begin{abstract}
This framework of the study is a quasi-experimental research. The purposes of this study were to develop the-Learning lesson, to compare students' translation learning ability before and after using the e-Learning lesson and to study the satisfaction of the English pre-service students in Basic Translation Course. The participants were 48 of English sophomore students, Faculty of Education, Suratthani Rajabhat University in the second semester of the 2017 academic year. The instruments employed in the experimental comprise of e-Learning lesson in Basic Translation Course, the test of translation learning used as a pre-test and post-test and the satisfaction questionnaire. The data were statistically analyzed by percentage, mean, standard deviation and t-test for dependent. The research findings indicated that the efficiency of the-Learning lesson in Basic Translation was at 75.12/77.86. The students' achievement after learning by using the e-Learning lesson in Basic Translation Course was significantly higher than before at the .05 level. The satisfaction of the students on the e-Learning lesson in Basic Translation Course was at a high level.
\end{abstract}

Keywords: e-Learning, translation ability, satisfaction

\section{Introduction}

\section{Importance of the study}

In this era of the $21^{\text {st }}$ century, modern classroom cannot be rejected online learning. For the new generation the habit and learning preferences has changed. Students can learn anywhere far from their classroom and enhance their soft skills and knowledge by using technology (Edelsonet al, 1999). Teachers need to manage learning activities to meet students' requirements and goal of education that looks difference from the traditional classroom (Callaghan and Bower, 2012). The learning environment becomes a borderless area due to information-accessed classroom by using educational technology and media for helping students learn more about knowledge and necessary skills (Herreid and Schiller, 2013).

In language learning in Basic Translation course, ability for communicative skills has an important role in the second language acquisition. Students need to develop in the light of general translation theories and models. Translation contains different mental activities such as language, thinking, problem solving, memory, conceptualization, learning, information processing, perception, understanding, re-expression etc. which makes translation a complex phenomenon. (Fadime, 2015). Translation has moved to different areas especially due to the impact of the developments in communication technology and current conditions. Therefore it requires the ability of quickly choosing among many alternatives and making decisions. What is important for translator is not to know everything, but to know how and where to find that information when needed, and choose the most appropriate one (Pym, 2012). The use of educational technology and media for helping students learn more about knowledge that is one of the most efficient methods to make the student have their real learning skills.

Researcher had undertaken to research this in my capacity as an English as a foreign language (EFL) teacher in a government university. The researcher face problems in effectively teaching translation skills such as lack of misconception of English language structure, equipment and materials and the lack of self-awareness in error 
correction. The subjects in my research are my English sophomore students. They studied the Basic Translation Course in my class and found it difficult to interpret the English texts and sometimes because the lessons are time prohibitive and are not conductive to allow the researcher to check their work in class so I try to find a method to solve this problem. There are many modern techniques that are designed to help students but I choose the e-Learning to blend it to my after-class learning.

\section{What is the Quipper School Application?}

Quipper School Application is a free online platform for teachers and students. It consists of two parts: LINK for teachers, and LEARN for students. Its School Link is where teachers manage their classes online and check students' progress. The teachers can create educational content, send assignments and practice examinations.

The School Learn is where students study. It's packed with features that make learning safe and fun. Students can work on specific topics proscribed by their teachers or study any part of their curriculum independently. LEARN rewards students with redeemable coins, allows them to customize their learning environment, and check how their classmates are getting on the Timeline.

\section{How does the Quipper School Application work?}

Teachers recreate their real life classes online, set study tasks in the form of bite-sized topics that help their students to progressively build knowledge, and receive simple, digestible analytics pointing out their students' progress as they work through the curriculum. The Quipper School Application works in three simple steps:

Step 1. Teacher set tasks online.

Step 2. Students complete their tasks, or work on any other part of the curriculum independently.

Step 3.As students work, teachers instant feedback on student performance.

\section{Objectives}

1. To construct the e-Learning lesson by using the Quipper School Application based on the Basic Translation Course of efficiency ratio at 75/75.

2. To compare students' English listening ability before and after using the Quipper School Application based on the Basic Translation Course.

3. To study the satisfaction level of the students on the Quipper School Application based on the Basic Translation.

\section{Research Methodology}

\section{Research Design}

The research framework of this study (see Table 1) is a quasi-experimental research in form of one group pretest and posttest design. The experiment carries out in the first semester of 2017 academic year and the experiment with the Quipper School Application based on the Basic Translation Course .The study includes forty-eight participants. Prior to the experiment, the participants are measured in their translation ability by using a pretest. Then, posttest is given to each participant after all of them using the Quipper School Application based on the Basic Translation Course. After completing the research, students who study the Basic Translation course with the Application do the satisfaction questionnaires. 
Table 1: Research Framework

\begin{tabular}{l|l|l}
\hline Pretest & Treatment & Posttest \\
\hline $\mathrm{O}_{1}$ & $\mathrm{X}$ & $\mathrm{O}_{2}$ \\
\hline
\end{tabular}

$\mathrm{O} 1=$ Pretest

$\mathrm{X}=$ Treatment; the Quipper School Application based on the Basic Translation Course

$\mathrm{O} 2=$ Posttest

\section{Research Participants}

The participants of the study are 48 of English sophomore students who study the Basic Translation of English program, Faculty of Education at Suratthani Rajabhat University in the second semester of 2017 academic year.

\section{Research Instruments}

The Quipper School Application

The Quipper School Application which is a new free e-learning service designed for teachers. This allows researcher to set assignments which the researcher as the teacher to track the student's progress online. It is worth remembering that today's students are of the technological generation and all seem to really enjoy interactive e-learning on their smart devices. The Application consists of two parts of learning and twelves units of basic translation contents and exercises as follow: PART I English to Thai Translation Unit 1.1 Subject-verb Agreement, Passive Voice, Tense, Unit 1.2 Connective \& Pronoun, Unit 1.3 Relative Clause, Unit 1.4 head Noun \& Modifier, Unit 1.5 Dummy Subject, Unit 1.6 Participle \& Phrasal Verb and PART II Thai to English Translation Unit II Unit 2.1 Passive \& Article, Unit 2.2 Ellipsis \& Topic-Comment, Unit 2.3 Topic \& Pronoun Particle, Unit 2.4 Definite \& Indefinite of Noun Phrase, Unit 2.5 Participle \& Serial Verb and Unit 2.6 Modifier $\&$ Tense

Pretest and Posttest

Every participant takes a pretest to identify their translation ability before using the Quipper School Application based on the Basic Translation Course. All participants are given the posttest after using the Application. The results of pretest and posttest are compared.

Satisfaction questionnaire

Student satisfaction questionnaires consisted of 20 items to be rated from 5 (highest) to 1 (lowest). These questionnaires were then quantitatively analyzed to get the overall satisfaction rate.

\section{Data collection}

The study used on group pretest and posttest quasi-experimental design. The data collection involved pretest manipulation with 48 participants. The subjects were assigned to do the pretest translation ability test before using the Quipper School Application based on the Basic Translation Course. The experiment carried out in one semester of the 2017 academic year. After completion, the subjects were assigned to do posttest translation 
ability test and to study the satisfaction of the students on the Application based on the Basic Translation Course.

\section{Data Analysis}

The data was analyzed by using mean, standard deviation, percentage and t-test for dependent.

\section{Results and Discussion}

\section{The Quipper School Application}

Table 2: The Quipper School Application based on the Basic Translation Course

\begin{tabular}{|c|c|c|c|c|}
\hline \multirow{2}{*}{$\begin{array}{l}\text { The Quipper School } \\
\text { Application based on the } \\
\text { Basic Translation Course }\end{array}$} & \multirow{2}{*}{$\mathrm{N}$} & \multicolumn{2}{|l|}{ Score } & \multirow{2}{*}{$\mathrm{E}_{1} / \mathrm{E}_{2}$} \\
\hline & & Full score & Average score & \\
\hline Formative scores & 48 & 220 & 165.26 & 75.12 \\
\hline Summative scores & 48 & 30 & 23.36 & 77.86 \\
\hline \multicolumn{4}{|l|}{$\mathrm{E}_{1} / \mathrm{E}_{2}$} & $75.12 / 77.86$ \\
\hline
\end{tabular}

As shown in Table 2, the results of experiment, the Quipper School Application based on the Basic Translation Course had efficiency at 75.12/77.86 that met the specified criteria 75/75.

\section{The test score analysis}

Table 3: Pretest and Posttest mean score of the translation ability test

\begin{tabular}{llll}
\hline Score & N & Mean & Percentage \\
\hline Pretest & 48 & 13.90 & 46.33 \\
Posttest & 48 & 24.87 & 82.90 \\
\hline
\end{tabular}

Table 4: T-test analysis of pretest and posttest mean score of the English translation ability test

\begin{tabular}{llllll}
\hline Score & $\mathrm{N}$ & Mean & S.D & t & Sig. \\
\hline Pretest & 48 & 35.63 & 2.95 & $-22.82^{*}$ & .000 \\
Posttest & 48 & 43.33 & 2.77 & & \\
\hline
\end{tabular}

$\mathrm{p}<.05$

The average percentage pretest and posttest score were presented in Table 3 with the percentage of 46.33 for the pretest and 82.9 for the posttest. The results from paired sample t-test of SPSS analysis show that the posttest mean score of the test is significantly higher than the pretest mean score $t=-22.82, \mathrm{p}<.05$ with the mean score of pretest and posttest $13.90($ S.D. $=2.95)$ and $24.87($ S.D. $=2.77)$ respectively as shown in Table 4.

\section{Satisfaction questionnaire}

The analysis of the students' satisfaction questionnaire indicated that the students who study with the Quipper School Application based on the Basic Translation Course had positive perceptions and intentions. The average 
rate of satisfaction was 3.97. The questionnaire was used after completing the research. Overall, the satisfaction of the students on the e-Learning based on the Basic Translation Course was at a high level.

Table 5: Satisfaction of the students on the e-Learning based on the Basic Translation

\begin{tabular}{l|l|l|l}
\hline Satisfaction Evaluation & $\bar{X}$ & S.D. & Satisfaction level \\
\hline 1. Element of e-Learning Lesson & 4.11 & 0.70 & High \\
\hline 2. Content of e-Learning Lesson & 4.03 & 0.70 & High \\
\hline 3. Benefit of e-Learning Lesson & 3.83 & 0.69 & High \\
\hline Average overall satisfaction & 3.97 & 0.70 & High \\
\hline
\end{tabular}

\section{Conclusions}

According to the result found in this study, the efficiency of e-Learning Lesson by using the Quipper School Application based on the Basic Translation Course was at 75.12/77.86. It showed that the e-Learning Lesson has the efficient tool for the course. The before and after test scores in basic translation ability after learning by using the Application based on the Basic Translation Course was significantly higher than before at a .05 level. The overall satisfaction of the students on the Application based on the Basic Translation Course was at a high level. It means the e-Learning was a suitable tool for English sophomore students who study the Basic Translation course of the English program in Faculty of Education, Surratthani Rajabhat University for increasing their basic translation skill. Moreover, it was a means for increasing students' satisfaction to enhance their basic translation skill.

\section{Acknowledgements}

First, the author sincerely appreciated to Surrathani Rajabhat University for financial support in this study. Second, I would like to thank my research advisors Dr.Supanrigar Watthanaboon, Dr.Parrusaya Kiatkheeree and Dr.Nattapakal Kitticunthonphisarn for their invaluable advice, encouragement, and editing. Furthermore, I also sincerely thank Assistant Professor Anchaleeporn Mankong for her valuable guidance and patient proof reading towards the completion of this research. Finally, I would also like to thank my English sophomore students who were a big important part of this research study.

\section{References}

Callaghan, N. \& Bower, M., 2012.Learning through social networking sites- the critical role of the teacher.Educational Media International, 49(1), 1-17.

Edelson D.C., Gordin, D.N. \& Pea, R.D., 1999.Addressing the challenges of inquiry-based learning through technology and curriculum design.The Journal of the Learning Sciences, 8(3\&4), 391-450.

Fadime, C., 2015. Analysis and training of the required abilities and skills in translation in the light of translation models and general theories of translation studies. 'Social and Behavior Sciences' 197: 707-714.

Herreid, C.F. \&Schiller, N.A., 2013.Case studies and the Flipped Classroom.Journal of College Science Teaching, 42(5), 62-66.

Pym, A., 2012. Translation skill, sets in a machine, translation age, Intercultural Studies Group Universitat 